\title{
Н.В. Коритнікова
}

N.V. Korytnikova

\section{НАПРЯМИ ВПЛИВУ ІНТЕРНЕТ-ТЕХНОЛОГІЙ НА ПОЛІТИЧНЕ ЖИТТЯ СУСПІЛЬСТВА}

\begin{abstract}
The influence of internet-technologies on the political life and the directions of socio-political changes in connection with the distribution of network communications is described. On the one hand, the possibilities of internetcommunications favor the democratic processes. On the other hand, the internet-technologies are able to render a negative social influence. It is emphasized that empiric researches in this sphere will help to find the methods of solving the described problems.
\end{abstract}

Сучасні засоби політичної й масової комунікації, що відповідають характеристикам інформаційного суспільства, впливають на технології соціального керування, що вимагає від державних службовців застосування нових принципів роботи, як-то: дія на основі колективної відповідальності, ділового партнерства й співробітництва 3 громадськістю. Інтернет-технології, сприяючи інформатизації політичних інститутів, у кілька разів збільшують можливості використання інформації в рамках відносин держави й суспільства, повністю модифікуючи способи державного керування. Найбільш важливий внесок у розробку даного напряму внесли такі вчені: Л. Белініс, Г.В. Грачов, В.А. Гуторов, А.О. Давидов, С. Клифт, В. Ковалевський, Б.В. Марков, І.С. Мелюхин, І.Л. Морозов, Д.Н. Пєсков і ін. [див. 1-8].

Нова мережна реальність піднімає нові питання, які полягають у двоїстому характері поширення інтернет-комунікацій у політичній сфері: можливості мережі Інтернет можуть бути використані як для підтримки існуючого соціального порядку, так і з метою встановлення диктатури або анархії залежно від соціально-політичних і економічних умов. 3 одного боку, нові засоби комп'ютерних комунікацій, будучи за своєю суттю складовою частиною суспільного блага, застосовуються, як правило, для досягнення й підтримки стабільності в суспільстві. Теоретики, що підтримують дану точку зору, вважають, що використання інтернет-комунікації збільшує доступ до державної інформації і підвищує ступінь впливу з боку суспільства на прийняття політичних рішень за допомогою інтерактивної ідентифікації інтересів, а також усуває посередників у взаємодії громадян з державними структурами, тобто анонімність забезпечує захист особистої інформації. 3 іншого боку, з поширенням глобальних інформаційно-комунікативних технологій виникає небезпека проведення нових радикальних експериментів із соціального конструювання. Думка прихильників даної концепції грунтується на виявленні додаткових бар'єрів, що виникають при здійсненні основних принципів демократії, а саме: проблеми циф- 


\section{ПОЛІТИКА}

рової нерівності, нових маніпулятивних технологій, підвищення контролю за діяльністю окремої людини та ін.

Метою даної статті є розгляд соціально-політичних змін, що супроводжують розвиток інформаційного суспільства. Виходячи з такої постановки проблеми, у даній статті оцінюються можливості мережних засобів комунікації в реалізації електронної демократії; висвітлюється подвійність соціально-політичних змін, що відбивають суть проблеми використання мережі в політиці; позначаються ключові проблеми таких перетворень.

На думку теоретиків постіндустріального суспільства, ступінь інформатизації всіх соціальних процесів визначає рівень розвиненості суспільства в глобальній системі, що і є основною ознакою інформаційного суспільства. До глобальної інформаційної революції політтехнологи працювали за допомогою традиційних засобів масової комунікації, доступ до яких був обмежений колом можновладців. За допомогою стандартизованих масових комунікацій вони виходили на трансляцію культурних цінностей і форм поведінки, диктували власні погляди й думки, актуалізували необхідні проблеми для суспільних дискусій. Для інформаційного суспільства властиві інші орієнтації, де основним завданням взаємодії органів влади 3 суспільством стає досягнення при мінімальних фінансових витратах максимального впливу на людей. Розгляд застосування нових інформаційно-комунікативних механізмів у соціальній взаємодії й у політичних процесах говорить про зростання ролі знання в соціально-політичних процесах. Тому основна настанова трансформації держави в стан мережного суспільства реалізується шляхом проведення онлайнреферендумів і прямої участі громадян в обговоренні найбільш гострих проблем, а також участі в прийнятті адміністративних рішень через систему World Wide Web і електронну пошту.

Присутність у глобальному інформаційному просторі стає одним з визначальних напрямів самопрезентації для політичних акторів. Виходячи з висновків про віртуалізацію суспільства, за допомогою інтернет політичне середовище визначається вже не бінарною схемою ворог-друг, а віртуальними відносинами між образом і його символічним сприйняттям. Становлення Інтернету як засобу політичної комунікації обумовлює виникнення й поширення нових форм відносин, що припускають взаємодію образів і знаків за допомогою віртуального середовища глобальної мережі.

3 розвитком і поширенням у соціальній сфері глобальної мережі комп'ютерів з'явилися наукові концепції, спрямовані на вирішення проблеми відособленості індивіда й соціальних груп від реалізації політичної влади завдяки збільшенню їх участі в політичному житті й переходу до інформаційного способу державного керування. Сучасний розвиток мережних засобів комунікації дозволив поліпшити сучасні демократичні режими, розкриваючи більше інформації, сприяючи прозорості державної діяльності й розвиваючи нові форми політичної активності.

Мережа Інтернет як новий комунікаційний засіб надає нові можливості інтеракції одного з одним і роботи з інформацією незалежно від політичних заборон і цензури, що свідчить про іiі ліберальність і демократичність. Тому вважається,

\section{0}


що нові комунікаційні засоби надають шанс перейти від моделі поліархії [див. 9] до віртуальної моделі ідеальної держави як синтетичної форми прямої, партиципаторної (демократія участі) і консенсусної (демократія обговорення, узгодження) демократії.

Становлення нових категорій соціологічної науки й долучення їх до політичної практики ще не має однозначної інтерпретації. Сформована спеціальна термінологія описує нові можливості проектів щодо практичної реалізації моделі ідеальної держави. Існують різні варіації назви такої моделі: “модемна демократія", “цифрова (діджітальна) демократія" (digital democracy), “кібернетичний поліс", "кіберполітика”, “кібердемократія” (суberdemocracy), “комунікаційна демократія”, “комп”ютерно-опосередкована демократія" (computer-mediated democracy), “електронне громадянство", “віртуальна демократія" (virtual democracy), “інформаційна демократія" (informational democracy) і т.д. У цілому вони позначають застосування нових інформаційних технологій у всіх видах політичного життя. У цей час частіше застосовується мово сполучення “електронна демократія" (electronic democracy), тому що слово “електронний” має на увазі застосування глобальних інтерактивних технологій. У даній роботі буде використане саме це поняття як найбільш усталене в соціології багатьох країнах світу.

У політологічному контексті “електронна демократія” розуміється як “будь-яка демократична політична система, у якій комп'ютери й комп”ютерні мережі використовуються для виконання найважливіших функцій демократичного процесу, таких як поширення інформації й комунікація, об’єднання інтересів громадян і прийняття рішень (шляхом наради й голосування)" $[10,11]$. У комунікативному аспекті М. Н. Грачов розглядає поняття "електронної демократії” як “заснований на застосуванні мережних комп'ютерних технологій механізм забезпечення політичної комунікації, що сприяє реалізації принципів народовладдя й дозволяє привести політичний устрій у відповідність із реальними потребами інформаційного суспільства, що знаходиться в стадії становлення" [12, с. 93]. Даний концепт нової демократії вміщає всілякі форми "e-(electronic)"теорій, тобто поєднує такі категорії, як “електронний уряд”, “електронна держава”, “електронне голосування”, “електронна комунікація”, “електронна нерівність”, “електронне шпигунство” і т.д. В результаті термін “електронна демократія" містить у собі онлайнову правозахисну діяльність, електронне проведення передвиборчих кампаній, використання мережної комунікації в політичній боротьбі.

Ключова мета електронної демократії полягає в тому, що вона дозволяє громадянам брати участь у роботі органів влади, а державі, у свою чергу, більш чуйно реагувати на потреби суспільства. Впровадження подібних проектів сприяє виникненню погляду на Інтернет, як на простір для розробки й апробації соціально-політичних стратегій розвитку суспільства 3 наступними виправленнями 3 метою досягнення максимального ефекту в модернізації соціальної системи. Узагальнення теоретичних тез прихильників розглянутих концепцій дозволяє виділити як принципи електронної демократії такі характеристики: доступність, інтерактивність, партиципаторність і узгодженість. 


\section{ПОЛІТИКА}

Доступність - вирішення проблеми доступу до інформації про діяльність політичних інститутів: для кожної людини в оперативному порядку розкриваються проекти законів, аналітичні матеріали, поточна інформація і т.д. “Завдяки виникненню нових форм опосередкованого публічного доступу до інформації, доступність відомостей про будь-яку дію або подію перестала залежати не тільки від кількості людей, що безпосередньо спостерігали за нею у момент іiі здійснення, але й від фактичного місцезнаходження “джерела" і “споживача" інформації як у просторі, так і в часі” [13, с. 99]. Незважаючи на досить високий ступінь відкритості традиційних засобів масової інформації, комп'ютерні комунікативні технології ще більшою мірою мають здатність зробити державну владу більш прозорою й відповідальною. Спрощення і ненав'язливість процесу інформування тепер дозволяє здійснювати індивідуалізовану доставку повідомлень, приділяючи увагу особливостям кожної групи і подаючи інформацію залежно від рівня зацікавленості. Очікувана прозорість, відкритість і відповідальність офіційних джерел приведе до збільшення капіталу суспільної довіри населення до політичних інститутів.

Інтерактивність - забезпечення постійного інтерактиву, тобто безперервного зворотного зв'язку. Зменшуючи в кілька тисяч разів витрати на зв'язок, мережні комунікації забезпечують одночасний і практично миттєвий контакт між собою необмеженої кількості громадян без просторово-часових меж. Тепер ніхто не залежить від наближеності до засобів масової комунікації, для того щоб висловити власну точку зору й відстояти свою думку. За допомогою глобальної мережі Інтернет усі можуть адресувати створені повідомлення мільйонам людей. Завдяки таким характеристикам Інтернет дає потенційну можливість будь-якому учаснику політичного процесу безперервно спілкуватися й збирати навколо себе однодумців, а також кожному бути почутим і брати участь у вирішенні актуальних політичних питань на національному й глобальному рівні, наприклад, за допомогою онлайн-референдумів.

Партиципаторність електронної демократії базується на використанні новітніх інформаційно-комунікаційних технологій для реалізації цивільних прав, свобод та інтересів, що є основою прямої демократії. Партиципація дозволяє включати в процес політичної соціалізації громадян, які по-різному ставляться до політики, діяльності державної влади, у силу особистих причин не беруть участі в політичних кампаніях, але прагнуть на місцевому рівні брати участь у вирішенні політичних, економічних і соціальних проблем. Завдяки новітнім технологіям індивід завжди може одержати необхідну суспільно або індивідуально значиму інформацію і долучитися до процесу прийняття політичних рішень [14, с. 214-222]. Головна перевага полягає в тому, що найчастіше політична партиципація буде мати особистісну спрямованість на досягнення мети в інтересах соціальної групи, яку представляє індивід. Збільшується кількість активних громадян, що бажають брати постійну участь у громадському житті.

Узгодженість - процедура обговорення актуальних питань, установлення діалогу на основі високого рівня поінформованості учасників і вироблення оптимального на даний час погляду на політичні питання [14, с. 214-222]. Завдяки новим можливостям обєднуватися “за інтересами”, прямо і безпосередньо відстоювати

\section{2}


свої інтереси істотно змінюється інститут лобізму - діяльності соціальних груп, що добиваються певних політичних та інших цілей. Відносно дешеві моментальні опитування-голосування з різних соціально-політичних проблем у масштабі цілої країни або окремого регіону з метою впливу на законодавців і посадових осіб ведуть до виникнення нового способу вирішення питань та врахування інтересів. Використання електронного обговорення в законотворчій діяльності, опублікування пропозицій держави 3 метою ініціації широкої дискусії серед населення й наступного вивчення іiі результатів приведуть до появи віртуального посередника (офіційні веб-сайти) [5].

Ці принципи свідчать на користь розвитку структур електронної демократії та поширення відповідних проектів у будь-якій державі. Перспективи електронної демократії пов'язані з рівнем розвитку інформаційної інфраструктури та організаці$є ю$ освіти населення щодо можливості використання нових технологій. Соціальні й технологічні результати поширення глобальної мережі сприяють удосконаленню існуючих демократичних систем.

Водночас щодо широкого використання комп'ютерних технологій у політиці існують і інші точки зору, висловлюються сумніви, що розвиток електронної демократії веде до поліпшення роботи політичних інститутів. Розглянемо докладніше можливі негативні соціальні наслідки впливу інтернет-технологій на політичне життя суспільства. Будучи неієрархізованною глобальною мережею, Інтернет не в змозі позбавити суспільство за будь-якого демократичного режиму від соціальних нерівностей і забезпечити головні свободи. Інтернет здатний одночасно впливати на різні політичні процеси в прямо протилежному напрямі. Залежно від вектора застосування його можливості можуть використовуватися як для підвищення рівня участі громадян у політиці, так і для тотального контролю держави над своїм населенням.

Основні напрями перетворень соціальної взаємодії в сучасному суспільстві на основі інтернет-технологій - розширення доступу до інформації; установлення прямих і рівноправних зв'язків усіх з усіма; обмін символьними формами з використанням інтерактивних форм - дають можливість будь-якого соціального конструювання: від абсолютно анархічного суспільства до тоталітарної держави. Нарівні 3 ідеєю “електронної демократіі” можна обговорювати структури “електронного тоталітаризму” або “електронної анархії”. Тому необхідно враховувати, що соціально-політичні наслідки використання інтернет-технологій можуть привести до двох радикальних полюсів соціального конструювання, сутність яких прямо протилежна моделі ідеальної держави і принципам електронної демократії. Позначимо основні проблеми, що виникають внаслідок значного поширення й застосування інтернеткомунікацій у політичній сфері.

Цифрова нерівність. Розвиток інформаційних технологій загострює проблему цифрової нерівності, що проявляється в неоднаковому соціальному становищі людей через різний доступ до інформаційно-комунікативних технологій. У західних теоріях при описі цього феномену вживається спеціальний термін “digital divide", що означає поділ суспільства на основі використання інформаційних ресурсів залежно від володіння власністю й багатством, неоднакових статусів у системі управління i 


\section{ПОЛІТИКА}

влади, рівня освіти, віку, місця проживання й етнічного походження. Природно з'являються соціальні групи чи навіть класи, які найближчим часом не зможуть одержати доступ до глобальної мережі.

У цілому поняття цифрової нерівності проявляється як додатковий чинник соціальної нерівності. Хоча український сегмент Інтернету постійно й інтенсивно розвивається на кількісному і якістному рівні (так, наприклад, максимальна аудиторія Інтернету в Україні (Уанету) за вересень 2004 р. склала 2,18 млн. користувачів, це на 280 тис. осіб (15\%) більше, ніж у серпні), але доступ до Інтернету, за різними оцінками, має всього 7-10\% населення України. Крім того, великого значення набуває рівень фінансових вкладень у сферу інтернет-інфраструктури, що може стати ще однією причиною для територіальної сегрегації населення. У більшості регіонів цей показник набагато нижче - за кількостю користувачів Інтернет тільки чотири міста України мають показники вище п'яти відсотків: Київ (60\%); Дніпропетровськ (11\%); Одеса (7\%) і Львів (5\%) [15].

Наявність проблеми нерівного доступу до інформаційних технологій означає не тільки відсутність у частини суспільства доступу до благ мережних комунікацій, але й не дозволяє повною мірою використати їх тим, у кого немає навичок роботи з великими інформаційними потоками. Тому відносно політичних процесів проблема цифрової нерівності свідчить про те, що вплив на вироблення політичних рішень і формування стратегії державного розвитку поки існує винятково в сформованих раніше професійних груп лобістів, які, крім всього іншого, одержали у свої арсенали ще більше важелів впливу. Звичайні громадяни, навіть за наявності підключених до мережі комп'ютерів, і тепер не мають таких можливостей, які мають впливові й заможні люди.

Удосконалення маніпулятивних технологій. Мультимедійність, інтерактивність, анонімність і спеціалізація мережної комунікації збільшують ступінь їі психологічного впливу на особистість, а саме цілий ряд особливостей інтернет-комунікації як соціального середовища: наявність специфічної мови взаємодії ("смайликів", абревіатур, використання кольорів і розміру шрифту); специфічних норм взаємодії (допущення більшої розкутості в бік агресивності або дружелюбності); виборчої трансляuіï соиіальних ролей (так, наприклад, більша частина “віртуальних персон” наділяється атрибутами успішності й значимості) [16]. Як стверджують фахівці, мережа сприяє реалізації трьох основних класів людських потреб - у спілкуванні, у пізнанні й у розвазі - і надає безліч способів самопрезентації, інформаційної активності й соціальної включенності [див. 17; 18]. Використовуючи вдосконалену можливість прямого психологічного маніпулювання особистістю за допомогою комп'ютерної мережі, політтехнологи тепер здатні виробляти більше непомітну і точно спрямовану стратегію політичного впливу і управління суспільною думкою, а також дають масу нових способів для створення цілеспрямованої пропаганди, реалізації радикальних політичних кампаній.

Технічна недосконалість пошукових машин. Існують певні технічні й програмні обмеження пошукових машин, що становлять найважливіший засіб доступу до інформації в мережі. Розробники й творці пошукових машин зіштовхуються 3 тех-

\section{4}


нологічними обмеженнями, які в цей час визначають систематичне увімкнення й вимкнення, роблячи одні сайти відомими, а інші невидимими. У роботі Гелена Нюссбаума, Лукаса Д. Інтрона "Формування мережі: чому важлива політика пошукових машин” докладно описані деякі схеми маніпулювання результатами пошуку. Вони обманюють алгоритм ранжування за допомогою таких засобів, як наповнення тексту ключовими словами й використання невидимого або дрібного тексту. Пошукові машини на основі каталогів можуть створювати свої бази даних і визначати, що буде зберігатися в них. Критерії, використовувані редакторами при винесенні рішення про індексування сторінки, можуть бути розмитими. Унаслідок цього чиїйсь сторінці може бути відмовлено (без повідомлення), причому іiі творець не буде знати, що потрібно зробити для включення сайту в список каталогу. [19, с. 14-15]. Більшість користувачів мережі, не розбираючись глибоко в механізмах пошукових машин і способів виводів результатів у них, не мають свободи вибору інформації, тому що вони не усвідомлюють, що за будь-яких результатів пошуку в мережі представлена тільки частина інформації. Більше того, латентна загроза глобальної мережі як засобу комунікації полягає в тому, що телеглядачі і радіослухачі вже усвідомлюють потенційні способи маніпулювання їхньою поведінкою, тоді як користувачі мережі ще впевнені у свободі свого інформаційного вибору. "Користувач Інтернету вважає себе активним вибірником, оскільки переконаний, що потрапив на даний інформаційний ресурс самостійно, у відповідності зі своїми інтересами й вільний звернутися до альтернативних джерел у будь-який момент. Подібна “самовпевненість” може серйозно понизити поріг раціонально-критичного сприйняття інформації” [8, с. 142].

Крім розглянутих інфраструктурних і технічних проблем використання мережі в соціальній взаємодії, існують дві проблеми соціально-політичного характеру, що сприяють установленню або анархії, або автократії: проблема інформаційної безпеки держави й проблема конфіденційності приватного життя.

У світлі західної філософської традиції знання змінює людей, воно може робити людей кращими, але не всяке знання - це знання на благо. Перехоплення електронних листів, копіювання конфіденційної інформації, комп'ютерне шахрайство, небезпека комп'ютерних вірусів, які крадуть адреси електронної пошти з адресних книг і стирають жорсткі диски, тепер стали цілком повсякденною складовою робочого життя $[20$, с. 55]. У даний час будь-яка країна може зазнати збитків як від звичайних шахраїв, так і від міжнародних терористичних організацій, які скрупульозно накопичують інформаційні матеріали для подальшої їх аналітичної обробки й ведення інформаційної війни. 3'явилися засоби глобального пошуку й відстеження інформації, які будьякий користувач мережі може застосовувати в непорядних і незаконних діях.

"У такому світі, де все розповідається, найбільш доступною і найбільш смертельною зброєю стає розголошення, викриття", - так описує дійсність інформаційного суспільства Мілан Кундера в творі “Неспішність”. Дійсно, в умовах неминучої відкритості будь-якій публічній людині, й тим більше політикові, варто обережно застосовувати нові інформаційні технології у своїй діяльності. На відміну від традиційних 3MI, Інтернет має істотні особливості щодо глибини й масштабності поширення свого впливу на окрему людину. Показове художнє зображення М. Кундерою за- 


\section{ПОЛІТИКА}

лежності кожної людини від найменьшої затримки реакції перед об'єктивами кінокамер, а саме епізод поведінки публічної людини, що проявила розгубленість внаслідок епатажної витівки депутата, що поцілувався зі СНІДоносієм: “....иі кілька хвилин нерішучості обійшлися їй (публічній людині) дорого, тому що на неї були націлені кінокамери, i незабаром у тележурналі (читай - у глобальній мережі Інтернет) вся Франція (читай - увесь світ) дивилася на їі обличчя, на всі три фази замімання, дивилася - і посміхалася" [21, с. 18-19]. У мережевому суспільстві успішність політика буде визначатися за рахунок навичок говорити, виступати з промовами, вигідно триматися перед камерою, а також здатності швидко реагувати на мінливу обстановку. Політична діяльність в умовах мережевого суспільства зводиться до професійного ведення дискусії, уміння знаходити вихід зі складних і гострих соціальних проблем, що вимагають негайного рішення. Висока залежність політичного процесу від віртуальних містифікацій підтверджує “анархічні нахили” глобальної мережі.

Завдяки тому що в мережі практично відсутні просторово-часові обмеження, а також посередники інформаційного обміну, що цензурують правомірно або 3 особистих мотивів деякі матеріали, окрема людина іноді бере на себе роль засобу масової комунікації або цілого суспільного руху, що робить іiі самостійним і незалежним суб'єктом політичного життя. Разом із цим виникає загроза того, що люди ще не адаптувалися до нових засобів спілкування й не усвідомлюють особливостей їх функціонування, що не дозволить повною мірою застосувати мережевні комунікації. Наприклад, у користувачів як певної соціальної групи ще не сформована культура застосування нових комунікативних можливостей людини. Часто вони наївно думають, що досить тільки привселюдно висловити свою точку зору, щоб до їхньої думки прислухалися. На практиці ж необхідно не раз відстоювати свою позицію, надавати вагомі докази для залучення на свій бік союзників. Нові комунікативні можливості людини зумовлюють збільшення відповідальності окремої людини, яка може використати переваги інтернет-комунікацій як на благо, так і на шкоду.

У вирішенні проблеми інформаційної безпеки держава не залишається осторонь і активно розробляє юридичні, комп’ютерні й системні способи контролю за діяльністю окремої людини в мережі. Для підвищення оперативності доступу до особистих справ кожного громадянина вся особиста інформація переводиться в електронну форму і їй приписується відповідний унікальний ідентифікаційний номер. Усім цим можуть скористатися не тільки відповідні державні органи, але й електронні шахраї. Потрапляючи до рук “крекерам" ("crackers" - зломщик, що прагне одержати закриту інформацію), приватні відомості що містяться у величезних банках даних, запросто можуть продаватися всім бажаючим. Що стосується пошуку прихованої інформації державними службами, то іноді виконання завдань національної безпеки може бути не цілком у згоді із законністю. Зокрема, Верна В. Герінг згадує дві програми моніторингу Інтернету, які ввело ФБР після 11 вересня: Carnivore (обмежувала користувачів, займаючись пошуком зашифрованого матеріалу) і Echelon (перехоплювала всі телекомунікаційні сигнали) [20, с. 64-65] У тому числі існують і інші форми використання приватної інформації: пристрій для перехоплення електронної пошти “Тимчасова поштова скринька” (Японіі); системи опера-

\section{6}


тивно-розшукових заходів на мережах документального електрозв'язку COPM i СОРМ-2 (Росія). Усе це впирається в проблему конфіденційності приватного життя в мережі. Будь-які нововведення в подібній сфері призводять до "тоталітарних нахилів" розвитку глобальної мережі через створення глобальної системи спостереження за мережевою діяльністю кожного користувача, програми нейтралізації інформаційно-політичних атак, нав'язування власної ідеології шляхом контролю за інакомислячими і т.д. Подібні технології дають необмежені можливості збору інформації про користувачів і застосовувати їх у своїх інтересах. На жаль, поки ще ніхто не зміг створити систему захисту приватної інформації від несанкціонованих зломів, розробити програму, що гарантує недоторканність електронного листування й телефонних розмов. Усе це серйозно гальмує повноцінний розвиток Інтернету як комунікативного засобу політичних інститутів, перетворюючи його в засіб спостереження, контролю й впливу на користувачів.

Через інформаційні й технічні нововведення сучасні демократичні системи тепер уже не зможуть залишатися без змін. Глобальне поширення нових засобів комунікації призведе до відчутних перетворень у політичному житті. Може бути створена інфраструктура електронної демократії. Автори концепцій, що підтримують ідею електронної демократії як моделі ідеальної держави, вважають, що мережеві комунікації служать установленню й удосконаленню демократичного політичного режиму. Аргументами для впровадження нової демократії є такі основні принципи: інтерактивність глобальних взаємодій, узгодженість дій, партиципація в прийнятті політичних рішень, доступність будь-якої офіційної державної інформації. Зазначені характеристики здатні перебороти ієрархізм існуючої влади, установити паритетність у здійсненні політики й забезпечити простір для самостійного представлення позиції активних користувачів і адекватної реалізації їхньої політичної діяльності. Вищеописані достоїнства електронної демократії змінюють традиційні політичні інститути, створені й функціонуючі під колишні інститути влади (держава, 3МІ, політичні партіі). В інформаційному суспільстві використання інтернет-комунікації призведе до більшої результативності в організації соціально-політичної взаємодії, що надасть нові можливості й для захисту вже наявних свобод особи. Це дозволить також відійти від громіздких структур державної бюрократії, забезпечити прозорість діяльності держави, включити громадян - користувачів мережі в політичне життя.

Проте введення в практику моделі ідеальної держави, заснованої на реалізації прямої демократії, стикається з труднощами, на які справедливо вказує інша група теоретиків. На їхню думку, цілком реально процес формування електронної демократії може призвести до цілком протилежних соціальних наслідків, а саме: примножить маніпулятивні технології, додасть додаткові фактори сегрегації населення, порушить інформаційну безпеку держави, збільшить можливості несанкціонованого вторгнення в приватне життя.

Таким чином, соціально-політичні зміни, що виникають у зв'язку з масовим поширенням мережевих комунікацій, йдуть по двох прямо протилежних напрямах: $з$ одного боку, можливості інтернет-комунікації сприяють демократичним процесам, з іншого ж боку, - ставлять під сумнів їх позитивні соціальні наслідки. Зазначене проти- 


\section{ПОЛІТИКА}

річчя послужило початку багатьох теоретичних і емпіричних досліджень, що допомагають знайти способи вирішення вищеописаних проблем. У вивченні політичної комунікації в Інтернеті акцент найчастіше робиться на підвищення частоти мережевих соціальних взаємодій, самоорганізацію віртуальних мережних співтовариств, установлення довірчих відносин між державою й населенням і т.д. Нові засоби комунікації в перспективі дозволяють вийти на більш високий рівень політичних інститутів.

1. Белинис Л. Электронная демократия: политика в условиях глобальной коммуникации // Журнал социологии и социальной антропологи. - 2003. - T. VI. - № 4 (24). - С. 67-81.

2. Грачев Г.В. Информационные технологии политической борьбы в российских условиях // Полис. - 2000. - № 3. - С. 151-156.

3. Гуторов B.A. Концепция киберпространства и перспективы современной демократии // Интернет и современное общество // http://ims98.nw.ru/cgi-bin/GET_TEZ0.exe? NUM_LINK=45

4. Давыдов A. О некоторых социально-политических последствиях становления сетевой структуры общества (2001) // http://www.futura.ru/index.php3?idart=109

5. Clift Steven. - http://www.publicus.net/

6. Марков Б.В. Демократия и интернет // Технологии информационного общества: Интернет и современное общество: Материалы Всерос. объедин. конф. (Санкт-Петербург, 20-24 нояб. 2000 г. - СПб, 2000. - 292 с.

7. Мелюхин И.С. Информационное общество: истоки, проблемы, тенденция развития, М.: Изд-во МГУ, 1999. - 208 с.

8. Морозов И.Л. Информационная безопасность политической системы // Полис. - 2002. № 5. - C. 134-145

9. Dahl R. Democracy and Its Critics. - New Haven: London, 1989. - P. 225.

10. Вершинин M.C. Политическая коммуникация в информационном обществе: перспективные направления исследований // Актуальные проблемы теории коммуникации: Сб. науч. трудов. - СПб: Изд-во СПб ГПУ, 2004. - С. 98-107.

11. Бондаренко C.B. Социальные технологии “электронной демократии” (попытка верификации конструкта) // http://www.adenauer.ru/report.php?lang=2\&id=279

12. Грачев М.Н., Мадатов А.С. Демократия: методология исследования, анализ перспектив. М.: Изд-во “АЛКИГАММА”, 2004.

13. Грачев М.Н. Средства коммуникации как инструмент преобразования социально-политической действительности. // Вестник Российского ун-та дружбы народов. - Сер. Политология. - 2001. - № 3. - С. 88-103.

14. Ковалевський В. Інформаційна демократія як політична категорія // Наук. записки: Зб. - К.: ІПіЕНД, 2003. - Сер. "Політологія і етнологія". - Вип. 22. - С. 214-222

15. http://company.mytop-in.net/news/2004/11/08/477796.html

16. Белинская Е.П. Человек в информационном мире // http://psynet.by.ru/texts/bel3.htm

17. Шмелев А.Г., Рыхлевская Е.И., Ларионов А.Г. Психологические аспекты самопрезентации пользователей Интернета // 2-я Российская конференция по экологич. психологии: Тезисы. - М., 2000 - С. 270-271.

18. Гуманитарные исследования в Интернете / Под ред. А.Е. Войскунского. - М.: МожайскTeppa, 2000.

19. Нюссбаум Х., Интрон Л. Формирование сети: почему важна политика поисковых машин // Интернет в обществ. жизни. - М.: Идея-Пресс, 2006. - С. 12-38.

20. Геринг В. Оказывают ли хакеры услугу обществу? // Интернет в общественной жизни. - М.: Идея-Пресс, 2006. - 160 с.

21. Кундера М. Неспешность. - М.: Иностр. Лит., 2000. - С. 18-19.

\section{8}

